Note

\section{The Structure of Zinnolide, a New Phytotoxin from Alternaria solani}

\section{Akitami IchIHARA, Hiroyuki TAZAKI and Sadao SAKAMURA}

Department of Agricultural Chemistry, Faculty of Agriculture, Hokkaido University, Sapporo 060, Japan

Received April 19, 1985

Although a number of phytotoxins have been isolated from Alternaria solani, ${ }^{1)}$ a causal fungus of the early blight disease of tomato and potato, the presence of other phytotoxins has been suggested. ${ }^{2)}$ Very recently, we reported the structural determination of three new phytotoxins, solanapyrones $\mathrm{A}, \mathrm{B}$ and $\mathrm{C}$, from the culture filtrate of the fungus. ${ }^{3,4)}$ In our continuing search for isolation of phytotoxins, we have further examined the culture filtrate of the fungus and isolated a new phytotoxin named zinnolide (1) through the procedure described in EXPERIMENTAL.

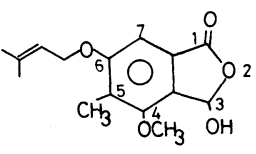

1

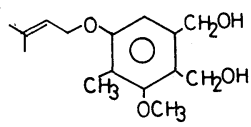

2

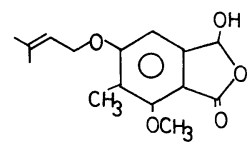

攵

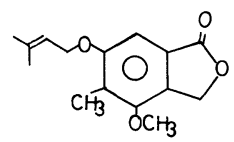

$\stackrel{3}{\sim}$

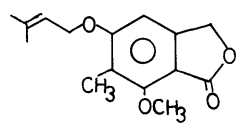

$\stackrel{4}{\sim}$

Zinnolide (1), a colourless solid, mp $171 \sim 173^{\circ} \mathrm{C}$, has the molecular formula $\mathrm{C}_{15} \mathrm{H}_{18} \mathrm{O}_{5}$ from its high resolution mass spectrum. The IR spectrum showed absorption bands at $3200 \mathrm{~cm}^{-1}$ due to a hydroxyl group and at $1720 \mathrm{~cm}^{-1}$ due to a carbonyl group and at $1600 \mathrm{~cm}^{-1}$ due to a phenyl group. Since the ${ }^{1} \mathrm{H}$ NMR spectrum exhibited characteristic signals at $\delta 2.69(3 \mathrm{H}, \mathrm{s}), 2.75(3 \mathrm{H}, \mathrm{s}), 4.45$
$(2 \mathrm{H}, \mathrm{d}, J=7 \mathrm{~Hz})$ and $5.35(1 \mathrm{H}$, br.t, $J=7 \mathrm{~Hz})$ ascribable to a prenyl moiety, at $\delta 2.13(1 \mathrm{H}, \mathrm{s})$ assignable to a methyl group on an aromatic nucleus, and at $\delta 3.90(3 \mathrm{H}, \mathrm{s})$ attributable to a methoxyl group, it was deduced that the phytotoxin had a closely related structure to that of zinniol (2), which has been isolated from the phytopathogenic fungus Alternaria zinniae. ${ }^{5)}$ Extensive comparison between zinnolide (1) and zinniol (2) by the ${ }^{1} \mathrm{H}$ NMR spectrum revealed that two hydroxymethyl groups in $\mathbf{2}$ were completely missing in $\mathbf{1}$. Instead, the presence of a lactol moiety $\left(\delta 6.60,1 \mathrm{H}, \mathrm{O}-\mathrm{C}^{\prime} \mathrm{HOCO}\right)$ was deduced in zinnolide 2. In fact, reduction of 1 with $\mathrm{LiAlH}_{4}$ in ether afforded a diol, whose spectral data were completely identical with those of authentic (2) in all respects. Therefore, two possible structures $\mathbf{1}$ or $\mathbf{1 a}$ were tentatively assigned to zinnolide. The lower field shift $(\delta 6.85)$ of the aromatic proton $(7-\mathrm{H})$ of $\mathbf{1}$ compared with that $(\delta 6.66)$ of 2 indicates that the lactone carbonyl was located at a peri position to $7-\mathrm{H}$ and effectively deshields the proton. This fact suggests the preferable structure $\mathbf{1}$ for zinnolide. It is known that chromic acid oxidation of zinniol (2) yields two isomeric phthalides $3\left(\mathrm{mp} 85 \sim 86^{\circ} \mathrm{C}\right)$ and $4\left(\mathrm{mp}^{\text {. }}\right.$ $\left.106 \sim 108^{\circ} \mathrm{C}\right){ }^{5)}$ In order to confirm the correct structure, zinnolide (1) was treated with $\mathrm{NaBH}_{4}$ in THF to yield a phthalide $\mathrm{mp} 84 \sim 86^{\circ} \mathrm{C}$. The spectroscopic data of the phthalide were identical with those of previously reported phthalide 3. Since this phthalide must therefore have the structure 3 , it follows that structure 1 represents zinnolide.

The phytotoxic effects of $\mathbf{1}$ on lettuce seedlings were examined by a growth test. Zinnolide (1) showed a $34.5 \%$ inhibition to the growth of the hypocotyl and $22.0 \%$ inhibition to the growth of the root at $100 \mathrm{ppm}$. The toxicity was rather weak compared with other phytotoxic metabolites, i.e., solanapyrones, from the same fungus.

\section{EXPERIMENTAL}

Melting points (mp) were measured on an MP-35 Yanaco Micro Melting Point Apparatus and are uncorrected. IR spectra were taken on a Hitachi 285 spectrometer. NMR spectra were recorded on an R-22 Hitachi High Resolution NMR Spectrometer $(90 \mathrm{MHz})$ and a JEOL FX 100 Spectrometer $(100 \mathrm{MHz})$, and MS were run on JEOL JMS-D 300 and JEOL JMS-DISG2 Mass Spectrometers,

Cultures and isolation. The fungus was grown in $500 \mathrm{ml}$ flasks containing $150 \mathrm{ml}$ of potato-sucrose medium at $25^{\circ} \mathrm{C}$ for 25 days in the dark. The culture filtrates (15 liters from 100 flasks) were concentrated in vacuo to 1.5 liters below $40^{\circ} \mathrm{C}$, and the concentrate was acidified with $2 \mathrm{~N}-\mathrm{HCl}$ to $\mathrm{pH} 3.5$ and extracted five times with $\mathrm{CHCl}_{3}$ (5 liters). The combined extracts were dried over anhydrous $\mathrm{MgSO}_{4}$, and concentrated in vacuo to give a dark red residue $(2.74 \mathrm{~g})$, which was chromatographed on a silicic acid column (120 g, Wako gel C-200) eluting with benzene-EtOAc $(9: 1)$ to give fractions A-J. Fraction E 
$(155 \mathrm{mg})$ showed rather weak phytotoxic activity on the growth of lettuce seedlings. This fraction was chromatographed on a silicic acid column (Kiesel gel 60), eluting with benzene-EtOAc $(95: 5)$ and further eluting with benzeneEtOAc $(80: 20)$ to yield an eluate. The eluate was chromatographed by HPLC (HITACHI GEL 3019) using MeOH and $\mathrm{AcOH}(1.5 \%)-\mathrm{MeOH}$ as the eluant to yield zinnolide $(102 \mathrm{mg})$ as a colorless solid, $\mathrm{mp} 171 \sim 173^{\circ} \mathrm{C}$. UV $\lambda_{\max }^{\mathrm{EtOH}} \mathrm{nm}(\varepsilon): 220$ (32000), 260 (6600); IR $v_{\max }^{\mathrm{KBr}} \mathrm{cm}^{-1}: 3200$, $1720,1600,1120,1095 ;{ }^{1} \mathrm{H}$ NMR $(90 \mathrm{MHz}) \delta_{\mathrm{TMS}}^{\mathrm{CDCl}_{3}}: 1.69$ $\left(3 \mathrm{H}, \mathrm{s},=\mathrm{C}-\mathrm{CH}_{3}\right), 1.75\left(3 \mathrm{H}, \mathrm{s},=\mathrm{C}-\mathrm{CH}_{3}\right), 2.13(3 \mathrm{H}, \mathrm{s}$, $\left.\mathrm{ArCH}_{3}\right), 3.90\left(3 \mathrm{H}, \mathrm{s}, \mathrm{OCH}_{3}\right), 4.45(2 \mathrm{H}, \mathrm{d}, J=7 \mathrm{~Hz}$, $\left.-\mathrm{CH}_{2} \mathrm{O}\right), 5.35(1 \mathrm{H}$, br.t, $J=7 \mathrm{~Hz},=\mathrm{C}-\mathrm{H}), 6.60(1 \mathrm{H}, \mathrm{s},-$ OCHO-), 6.85 (1H, s, Ar-H). EI-MS $m / z 278\left(\mathrm{M}^{+}\right), 245$, 224, 210, 193, 69, HR-MS $m / z$ 278.1167; calcd. for $\mathrm{C}_{15} \mathrm{H}_{18} \mathrm{O}_{5}, m / z 278.1154$.

Reduction of zinnolide (1) to zinniol (2). To a solution of zinnolide $(20 \mathrm{mg}, 0.072 \mathrm{mmol})$ in anhydrous ether $(0.4 \mathrm{ml})$ was added dropwise a suspension of $\mathrm{LiAlH}_{4}$ $(8 \mathrm{mg}, 0.211 \mathrm{mmol})$ in anhydrous ether $(0.1 \mathrm{ml})$, and the mixture was refluxed for $4 \mathrm{hr}$ under a nitrogen atmosphere. After adding EtOAc and then $2 \mathrm{~N}-\mathrm{HCl}$, the reaction mixture was extracted three times with EtOAc. The combined extracts were washed with brine, dried over anhydrous $\mathrm{Na}_{2} \mathrm{SO}_{4}$ and concentrated in vacuo to give a residue, which was chromatographed on a silicic acid column to yield zinniol $(7 \mathrm{mg}, 36.6 \%$ ), whose spectral data were identical with those of an authentic sample. IR $v_{\max }^{\text {neat }} \mathrm{cm}^{-1}$ : $3350,2900,1600,1580,1450,1410 ;{ }^{1} \mathrm{H}$ NMR $(100 \mathrm{MHz})$ $\delta_{\mathrm{TMS}}^{\mathrm{CDCl}_{3}}: 1.74\left(3 \mathrm{H}, \mathrm{s},=\mathrm{C}-\mathrm{CH}_{3}\right), 1.80\left(3 \mathrm{H}, \mathrm{s},=\mathrm{C}-\mathrm{CH}_{3}\right)$, $2.15\left(3 \mathrm{H}, \mathrm{s}, \mathrm{Ar}-\mathrm{CH}_{3}\right), 3.75\left(3 \mathrm{H}, \mathrm{s}, \mathrm{OCH}_{3}\right), 4.51(2 \mathrm{H}, \mathrm{d}$, $\left.J=6.6 \mathrm{~Hz},-\mathrm{CH}_{2}-\right), 4.66\left(2 \mathrm{H}, \mathrm{s},-\mathrm{CH}_{2} \mathrm{O}\right), 5.46(1 \mathrm{H}$, br. t, $J=6.6 \mathrm{~Hz},=\mathrm{CH}), 6.67(1 \mathrm{H}, \mathrm{s}$, Ar-H $)$. EI-MS $m / z 266$ $\left(\mathrm{M}^{+}\right), 198,180,163,152$.

Reduction of zinnolide (1) to phthalide (3). A solution of zinnolide $(10 \mathrm{mg}, 0.036 \mathrm{~m} \mathrm{~mol})$ and sodium borohydride $(5.5 \mathrm{mg}, 0.145 \mathrm{~m} \mathrm{~mol})$ in anhydrous THF was stirred for $1 \mathrm{hr}$ at room temperature. After adding water, the reaction mixture was extracted three times with EtOAc. The combined extracts were washed with brine, dried over anhydrous $\mathrm{Na}_{2} \mathrm{SO}_{4}$ and concentrated in vacuo to give a residue, which was chromatographed on a silicic acid column using benzene-EtOAc $(3: 1)$ as the eluant to yield phthalide ( $8 \mathrm{mg}, 87.9 \%$ ), whose spectral data were identical with those of the authentic sample 3: white solid, mp $84 \sim 86^{\circ} \mathrm{C}$ (lit. ${ }^{5)} \mathrm{mp} 85 \sim 86^{\circ} \mathrm{C}$ ). UV $\lambda_{\max }^{\mathrm{EtOH}} \mathrm{nm}(\varepsilon): 256$ (7100), 302 (3400), IR $v_{\max }^{\text {neat }} \mathrm{cm}^{-1}: 2900,1760,1610,1110$; ${ }^{1} \mathrm{H}$ NMR $(100 \mathrm{MHz}) \delta_{\mathrm{TMS}}^{\mathrm{CDCl}_{3}} 1.75\left(3 \mathrm{H}, \mathrm{s},=\mathrm{C}-\mathrm{CH}_{3}\right), 1.80$ $\left(3 \mathrm{H}, \mathrm{s},=\mathrm{C}-\mathrm{CH}_{3}\right), 2.21\left(3 \mathrm{H}, \mathrm{s}, \mathrm{Ar}-\mathrm{CH}_{3}\right), 3.88(3 \mathrm{H}, \mathrm{s}$, $\left.\mathrm{OCH}_{3}\right), 4.57\left(2 \mathrm{H}, \mathrm{d}, J=6.6 \mathrm{~Hz},-\mathrm{CH}_{2}-\right), 5.38(2 \mathrm{H}, \mathrm{s}$, $\left.\mathrm{CH}_{2}\right), 5.49(1 \mathrm{H}$, br.t, $J=6.6 \mathrm{~Hz},=\mathrm{CH}), 7.08(1 \mathrm{H}, \mathrm{s}, \mathrm{Ar}-$ H). EI-MS $m / z 262\left(\mathrm{M}^{+}\right), 224,194,165,69$; HR-MS $m / z$ 262.1209; calcd. for $\mathrm{C}_{15} \mathrm{H}_{18} \mathrm{O}_{4}, m / z 262.1204$.

\section{Bioassay}

Growth inhibition of lettuce seedlings. An EtOAc solution $(1 \mathrm{ml})$ containing a sample $(0.3 \mathrm{mg})$ was poured on to a sheet of filter paper ( $7 \mathrm{~cm}$ diameter, Toyo-Roshi No.2) in a Petri dish ( $9 \mathrm{~cm}$ diameter). After removing the solvent in a desiccator, $3 \mathrm{ml}$ of a Tween- 80 solution ( $100 \mathrm{ppm}$ ) was added to the dish to make a $100 \mathrm{ppm}$ solution. Lettuce seeds (Great Lake) were placed on the filter paper and germinated in the dark at $23^{\circ} \mathrm{C}$ for 3 days.

Acknowledgment. The authors wish to thank Dr. N. Ishizaka, Hokkaido National Agricultural Experimental Station, Sapporo, for his gift of the strain, Alternaria solani ASP-2.

\section{REFERENCES}

1) J. F. Grove, J. Chem Soc., 4056 (1952); J. R. BartelsKeith, J. Chem. Soc., 860, 1662 (1960); A. Stoessl, Chem, Commun., 307 (1967); A. Stoessl, Can. J. Chem., 47, 767, 777 (1969); A. Stoessl, Can. J. Chem., 47, 767, 777 (1969); A. Stoessl, C. H. Unwin and J. B. Stothers, Tetrahedron Lett., 2481 (1979).

2) U. Matern, G. Strobel and J. F. Shepard, Proc. Natl. Acad. Sci. U.S.A., 75, 4935 (1978).

3) A. Ichihara, H. Tazaki and S. Sakamura, Tetrahedron Lett., 24, 5373 (1983).

4) A. Ichihara, M. Miki and S. Sakamura, Tetrahedron Lett., 26, 2453 (1985).

5) A. N. Starratt, Can. J. Chem, 46, 767 (1968). 